\title{
Netnography Study of Digital Democracy Forum (FDD) on Electronic Information and Transaction Law (UU ITE)
}

\author{
Nani Kurniasari \\ Institut Teknologi dan Bisnis Kalbis \\ Jakarta, Indonesia \\ nani.kurniasari@kalbis.ac.id
}

\begin{abstract}
The revolution of digital era has changed our lives in every way. The invention of social media change how people communicate to each other nowadays. Some communities use it as a new media for discussion. Whats App Group (WAG) is one of the most popular social media that been used by a community for a specific issue. Digital Democracy Forum (FDD) is one of the community that having specific issue in their group as a community that focusing on reinforcing the Electronic Information and Transactions Law (UU ITE). UU ITE been authorized by the government in 2008 , and considered harmful to the internet user because it is not emphasizes morality. Since its authorization, people encourage that the law needs to change and revised for a better use of it. FDD consist of Non-Governmental Organization (NGO), academics, and activist whose trying to advocate the needs of the law itself to be revised to become more effective and efficient. This research conducted with netnography methods as grounded theory. Primary data in this research will consist online observation and content analysis from hypertext interactions of FDD community in their Whats App Group. This research expect to disclose the government how to accommodate the aspirations of the people relating to the law reinforcement especially in the field of participating and giving opinion in the internet.
\end{abstract}

Keywords-community; internet; netnography; online public participation; $\boldsymbol{U} \boldsymbol{U} I T E$

\section{INTRODUCTION}

In the era of new media like today, the internet has become the media of choice of Indonesian audiences. Based on data from the Association of Internet Service Providers Indonesia (APJII), the number of internet users in Indonesia until the end of 2014 reached 88 million people. More than $80 \%$ of internet users in Indonesia access the internet at least once a day with average access for one hour per day, which is $35.3 \%$ of the total internet users in Indonesia [1].

Still according to APJII 2015, there are three main reasons Indonesian people access the internet, namely first, as a means of social / communication $(72 \%)$. Secondly, as a source of daily information (65\%), and third, keep up with the times $(51 \%)$. The three main reasons are practiced through four main activities: using social networking $(87 \%)$, seeking information
$(69 \%)$, instant messaging $(60 \%)$ and searching for the latest news $(60 \%)$.

Since the Internet infrastructure was developed by the Indonesian government in the 1980s, the number of users continues to increase. Increased use of internet access can be seen in many activities. Activities related to the increasing use of the internet in Indonesia such as use as an e-commerce media, social media, and even political campaign media. The complex of internet usage in Indonesia requires the government to formulate policies that regulate internet usage, that is Law no. 11 of 2008 on UU ITE.

In practice, the ITE Law is often reaping controversy. For human rights activists, the formulation of the criminal act of the UU ITE is too widespread and has no clear focus, so it is regarded as one of the examples of legislative products that are too criminal, whereas the government itself has not been optimal in socialization related to internet usage and new media literacy to internet users in Indonesia. Among police officers, the UU ITE is difficult because investigators need the court chairman's permission in detention.

Government policy related to internet usage is Law no. 11 of 2008 on UU ITE. Since passed, the ITE Act has been a lot of ensnare internet users in Indonesia. Many cases are actually not in accordance with the rules governed by the ITE Act. The following is a list of cases that hit internet users from 2009 to 2015.

TABLE I. LIST OF CASES THAT HIT INTERNET USERS FROM 2009 TO 2015

\begin{tabular}{|l|l|l|l|l|}
\hline No. Decision & Date & Defendant & \multicolumn{1}{c|}{ Court } & \multicolumn{1}{c|}{ Clause } \\
\hline $\begin{array}{l}\text { No. } \\
\text { 1269/PID.B/ } \\
\text { 2009/PN.TN } \\
\text { G }\end{array}$ & $\begin{array}{l}29 \\
\text { Des } \\
2009\end{array}$ & $\begin{array}{l}\text { Prita } \\
\text { Mulyasari }\end{array}$ & $\begin{array}{l}\text { Pengadila } \\
\text { n Negeri } \\
\text { Tangeran } \\
\text { g }\end{array}$ & $\begin{array}{l}\text { Pasal 45 ayat (1) } \\
\text { jo. Pasal 27 ayat } \\
\text { (3) UU ITE }\end{array}$ \\
\hline $\begin{array}{l}\text { No.PUT/137- } \\
\text { K/PM I - } \\
\text { 02/AD/X/201 }\end{array}$ & 2 Des & $\begin{array}{l}\text { Sophan } \\
\text { Harwanto } \\
\text { (Lettu Chb) }\end{array}$ & $\begin{array}{l}\text { Pengadila } \\
\text { n Militer } \\
\text { I - 02 } \\
\text { Medan }\end{array}$ & $\begin{array}{l}\text { Pasal 27 ayat (3) } \\
\text { jo Pasal 45 ayat } \\
\text { (1) UU ITE }\end{array}$ \\
\hline $\begin{array}{l}\text { No. } \\
\text { 232/Pid.B/20 } \\
\text { 10/PN.Kdl }\end{array}$ & 2011 Jan & $\begin{array}{l}\text { Drs. } \\
\text { Prabowo, } \\
\text { MM bin } \\
\text { Tjasan } \\
\text { Pramono }\end{array}$ & $\begin{array}{l}\text { Pengadila } \\
\text { Kendal Negeri }\end{array}$ & $\begin{array}{l}\text { Pasal 27 ayat (3) } \\
\text { juncto Pasal 45 } \\
\text { ayat (1) UU ITE } \\
\text { atau Pasal 311 } \\
\text { ayat (1) KUHP }\end{array}$ \\
\hline
\end{tabular}




\begin{tabular}{|c|c|c|c|c|}
\hline No. Decision & Date & Defendant & Court & Clause \\
\hline & & Saputro & & $\begin{array}{llr}\text { atau Pasal } 335 \\
\text { ayat (1) ke- } 2 \\
\text { KUHP } & \\
\end{array}$ \\
\hline $\begin{array}{l}\text { No. } \\
\text { 1190/PID.B } \\
\text { /2010/PN.TN } \\
\text { G } \\
\end{array}$ & $\begin{array}{l}16 \\
\text { Feb } \\
2011\end{array}$ & $\begin{array}{lr}\text { Drs. } & \text { Diki } \\
\text { Candra } & \text { bin } \\
\text { Didi Kustawa }\end{array}$ & $\begin{array}{l}\text { Pengadila } \\
\mathrm{n} \text { Negeri } \\
\text { Tangeran } \\
\mathrm{g}\end{array}$ & $\begin{array}{l}\text { Pasal } 45 \text { Ayat } \\
\text { (1) jo pasal } 27 \\
\text { ayat (3) UU ITE }\end{array}$ \\
\hline $\begin{array}{l}\text { No. } \\
\text { 23/Pid.B/201 } \\
\text { 1/PN-JTH }\end{array}$ & $\begin{array}{l}19 \\
\text { Apr } \\
2011\end{array}$ & $\begin{array}{l}\text { A.Hamidy } \\
\text { Arsa Bin } \\
\text { Abdurrahman }\end{array}$ & $\begin{array}{l}\text { Pengadila } \\
\text { n Negeri } \\
\text { Jantho }\end{array}$ & $\begin{array}{l}\text { Pasal } 45 \text { ayat (1) } \\
\text { jo pasal } 27 \text { ayat } \\
\text { (3) UU ITE atau } \\
\text { pasal } 45 \text { ayat (2) } \\
\text { jo pasal } 28 \text { ayat } \\
\text { (2) UU ITE }\end{array}$ \\
\hline $\begin{array}{l}\text { No.822 } \\
\text { K/Pid.Sus/20 } \\
10\end{array}$ & $\begin{array}{l}30 \\
\text { Jun } \\
2011\end{array}$ & $\begin{array}{l}\text { Prita } \\
\text { Mulyasari }\end{array}$ & $\begin{array}{l}\text { Pengadila } \\
\text { n Negeri } \\
\text { Tangeran } \\
\mathrm{g} \\
\text { Mahkam } \\
\text { ah Agung }\end{array}$ & $\begin{array}{l}\text { Pasal } 45 \text { ayat (1) } \\
\text { jo. Pasal } 27 \text { ayat } \\
\text { (3) UU ITE }\end{array}$ \\
\hline $\begin{array}{l}\text { No.116/PID/ } \\
\text { 2011/PT.DPS }\end{array}$ & $\begin{array}{l}13 \\
\text { Jan } \\
2012\end{array}$ & $\begin{array}{l}\text { Herrybertus } \\
\text { Johan Julius } \\
\text { Calame, S.Pd. }\end{array}$ & $\begin{array}{l}\text { Pengadila } \\
\text { n Negeri } \\
\text { Singaraja } \\
\text { Pengadila } \\
\text { n Tinggi } \\
\text { Denpasar }\end{array}$ & $\begin{array}{l}\text { Pasal } 27 \text { (3) jo. } \\
\text { Pasal } 45 \text { ayat (1) } \\
\text { UU ITE }\end{array}$ \\
\hline $\begin{array}{l}\text { No.45 } \\
\text { /Pid.B/2012/ } \\
\text { PN.MSH }\end{array}$ & $\begin{array}{l}12 \\
\text { Nov } \\
2012\end{array}$ & $\begin{array}{lr}\text { Leco } & \text { Maba } \\
\text { alias } & \text { Leco } \\
\text { alias Econ }\end{array}$ & $\begin{array}{l}\text { Pengadila } \\
\text { n Negeri } \\
\text { Masohi }\end{array}$ & $\begin{array}{l}\text { Pasal } 45 \text { ayat (1) } \\
\text { Jo Pasal } 27 \text { ayat } \\
3 \text { UU ITE }\end{array}$ \\
\hline $\begin{array}{l}\text { No. } 151 / \\
\text { PID/ 2012/ } \\
\text { PT.BTN. }\end{array}$ & $\begin{array}{l}29 \\
\text { Nov } \\
2012\end{array}$ & $\begin{array}{l}\text { dr. Ira } \\
\text { Simatupang, } \\
\text { Sp.Og } \\
\text { Binti } \\
\text { P.Simatupang }\end{array}$ & $\begin{array}{l}\text { Pengadila } \\
\mathrm{n} \text { Negeri } \\
\text { Tangeran } \\
\mathrm{g} \\
\text { Pengadila } \\
\mathrm{n} \text { Tinggi } \\
\text { Banten }\end{array}$ & 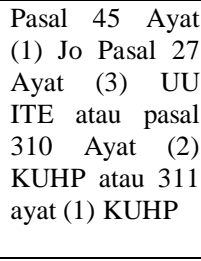 \\
\hline $\begin{array}{l}\text { No. } \\
\text { 01/Pid/2013/ } \\
\text { PT.MAL }\end{array}$ & $\begin{array}{l}29 \\
\text { Jan } \\
2013\end{array}$ & $\begin{array}{lr}\text { Leco } & \text { Maba } \\
\text { alias } & \text { Leco } \\
\text { alias Econ }\end{array}$ & $\begin{array}{l}\text { Pengadila } \\
\text { n Negeri } \\
\text { Masohi } \\
\text { Pengadila } \\
\text { n Tinggi } \\
\text { Maluku }\end{array}$ & $\begin{array}{l}\text { Pasal } 45 \text { ayat (1) } \\
\text { Jo Pasal } 27 \text { ayat } \\
3 \text { UU ITE }\end{array}$ \\
\hline $\begin{array}{l}\text { No. } \\
\text { 2357/Pid.B/2 } \\
\text { 012/PN.SBY }\end{array}$ & $\begin{array}{l}7 \\
\text { Mar } \\
2013 \\
\end{array}$ & $\begin{array}{l}\text { Yenike Venta } \\
\text { Resti }\end{array}$ & $\begin{array}{l}\text { Pengadila } \\
\mathrm{n} \text { Negeri } \\
\text { Surabaya }\end{array}$ & $\begin{array}{l}\text { Pasal } 45 \text { ayat (1) } \\
\text { junto pasal } 27 \\
\text { ayat (3) UU ITE }\end{array}$ \\
\hline $\begin{array}{l}\text { No. } \\
\text { 1832/Pid.B/2 } \\
012 / \text { PN.Jkt.S } \\
\text { el }\end{array}$ & $\begin{array}{l}3 \\
\text { Okt } \\
2013\end{array}$ & $\begin{array}{l}\text { Muhammad } \\
\text { Fajrika Mirza, } \\
\text { SH alias Boy } \\
\text { bin A. Ganie } \\
\text { Mustafa }\end{array}$ & $\begin{array}{l}\text { Pengadila } \\
\text { n Negeri } \\
\text { Jakarta } \\
\text { Selatan }\end{array}$ & 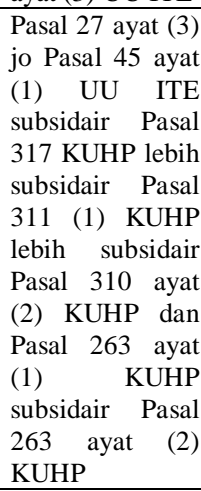 \\
\hline $\begin{array}{l}\text { No.1333/Pid. } \\
\text { Sus/2013/PN. } \\
\text { Jkt.Sel }\end{array}$ & $\begin{array}{l}5 \\
\text { Feb } \\
2014\end{array}$ & $\begin{array}{l}\text { Benny } \\
\text { Handoko } \\
\text { alias Benhan }\end{array}$ & $\begin{array}{l}\text { Pengadila } \\
\text { n Negeri } \\
\text { Jakarta } \\
\text { Selatan }\end{array}$ & $\begin{array}{l}\text { Pasal } 27 \text { ayat } 3 \\
\text { UU ITE Pasal } \\
45 \text { ayat (1) UU } \\
\text { ITE }\end{array}$ \\
\hline $\begin{array}{l}\text { No. } \\
\text { 45/Pid.Sus/2 } \\
\text { 013/PN.Pt. }\end{array}$ & $\begin{array}{l}18 \\
\text { Feb } \\
2014\end{array}$ & $\begin{array}{l}\text { Nunung } \\
\text { Setyaningrum } \\
\quad \text { SH binti }\end{array}$ & $\begin{array}{l}\text { Pengadila } \\
\mathrm{n} \text { Negeri } \\
\text { Pati }\end{array}$ & $\begin{array}{l}\text { Pasal } 27 \text { ayat } 3 \\
\text { jo pasal } 45 \text { ayat } \\
\text { (1) UU }\end{array}$ \\
\hline
\end{tabular}

\begin{tabular}{|c|c|c|c|c|}
\hline No. Decision & Date & Defendant & Court & Clause \\
\hline & & Karlan & & \\
\hline $\begin{array}{l}\text { No. } \\
\text { 33/PID.B/20 } \\
\text { 14/PN.DPU }\end{array}$ & $\begin{array}{l}12 \\
\text { Mei } \\
2014\end{array}$ & $\begin{array}{l}\text { Abraham } \\
\text { Sujoko alias } \\
\text { M. Faluid } \\
\text { Muka Safa }\end{array}$ & $\begin{array}{l}\text { Pengadila } \\
\text { n Negeri } \\
\text { Dompu }\end{array}$ & $\begin{array}{l}\text { Pasal 156a } \\
\text { KUHP atau } \\
\text { pasal } 27 \text { ayat (3) } \\
\text { jo pasal } 45 \text { ayat } \\
\text { (1) UU ITE }\end{array}$ \\
\hline $\begin{array}{l}\text { No. } \\
\text { 390/Pid.B/ } \\
\text { 2014/PN. } \\
\text { Mks }\end{array}$ & $\begin{array}{l}28 \\
\text { Mei } \\
2014\end{array}$ & $\begin{array}{l}\text { Muhammad } \\
\text { Arsyad, S.H. }\end{array}$ & $\begin{array}{l}\text { Pengadila } \\
\mathrm{n} \text { Negeri } \\
\text { Makassar }\end{array}$ & $\begin{array}{l}\text { Pasal } 27 \text { ayat } 3 \\
\text { UU ITE atau } \\
\text { Pasal } 310 \text { ayat } 1 \\
\text { KUHP atau } \\
\text { Pasal } 315 \text { KUHP }\end{array}$ \\
\hline $\begin{array}{l}\text { No. } \\
\text { 196/Pid.Sus/ } \\
\text { 2014/PN.BT } \\
\text { L }\end{array}$ & $\begin{array}{l}5 \text { Jan } \\
2015\end{array}$ & $\begin{array}{l}\text { Ervani Emy } \\
\text { Handayani } \\
\text { Binti Saiman }\end{array}$ & $\begin{array}{l}\text { Pengadila } \\
\mathrm{n} \text { Negeri } \\
\text { Bantul }\end{array}$ & $\begin{array}{l}\text { Pasal } 45 \text { ayat (1) } \\
\text { Jo Psl } 27 \text { ayat } \\
\text { (3) UU ITE atau } \\
\text { Pasal } 310 \text { ayat } \\
\text { (1) KUHP atau } \\
\text { Pasal } 311 \text { ayat } \\
\text { (1) KUHP }\end{array}$ \\
\hline $\begin{array}{l}\text { No.324/ } \\
\text { Pid.B/2014/P } \\
\text { N.SGM }\end{array}$ & $\begin{array}{l}18 \\
\text { Feb } \\
2015\end{array}$ & $\begin{array}{l}\text { Fadhli Rahim, } \\
\text { S.Sos bin } \\
\text { Abd Rahim } \\
\text { Hanapi }\end{array}$ & $\begin{array}{l}\text { Pengadila } \\
\mathrm{n} \text { Negeri } \\
\text { Sunggum } \\
\text { inasa }\end{array}$ & $\begin{array}{l}\text { Pasal } 27 \text { ayat } 3 \\
\text { jo. Pasal } 45 \text { ayat } \\
\text { (1) UU ITE }\end{array}$ \\
\hline $\begin{array}{l}\text { No. } \\
\text { 382/Pid.Sus/ } \\
\text { 2014/Pn.Yky }\end{array}$ & $\begin{array}{l}1 \\
\text { Mar } \\
2015\end{array}$ & $\begin{array}{l}\text { Florence } \\
\text { Saulina } \\
\text { Sihombing }\end{array}$ & $\begin{array}{l}\text { Pengadila } \\
\text { n Negeri } \\
\text { Yogyakar } \\
\text { ta }\end{array}$ & $\begin{array}{l}\text { Pasal } 27 \text { ayat } 3 \\
\text { jo. Pasal } 45 \text { ayat } \\
\text { (1) UU ITE }\end{array}$ \\
\hline $\begin{array}{l}\text { No : } \\
\text { 292/Pid.B/20 } \\
\text { 14/PN.Rbi }\end{array}$ & $\begin{array}{l}2 \\
\text { Mar } \\
2015\end{array}$ & $\begin{array}{l}\text { Ir. Khairudin } \\
\text { M. Ali, M.Ap }\end{array}$ & $\begin{array}{l}\text { Pengadila } \\
\text { n Raba } \\
\text { Bima }\end{array}$ & $\begin{array}{l}\text { Pasal } 27 \text { ayat (3) } \\
\text { jo. Pasal } 45 \text { ayat } \\
\text { (1) UU ITE jo. } \\
\text { Pasal } 64 \text { ayat (1) } \\
\text { KUHP Atau } \\
\text { Pasal } 310 \text { ayat } \\
\text { (2) jo. Pasal } 64 \\
\text { ayat (1) KUHP }\end{array}$ \\
\hline
\end{tabular}

On the basis of problems in the application of the ITE Act, many parties are encouraging the revision of UU ITE. Among these are the Institute for Criminal Justice Reform (ICJR), Legal Aid Institute (LBH) Press, Institute for Policy Research and Advocacy (ELSAM), Alliance of Independent Journalists (AJI), One World, SIKA, and Digital Democracy Forum (FDD).

As one of the communities pushing for the revision of UU ITE, the FDD considers that the ITE Act basically has to fulfill the political rights-both opinion and participation-on the internet. FDD is an open forum that strives for digital democracy for Indonesian society. FDD formed a discussion group in WAG as a means of communicating among its members. Created on October 2, 2013, WAG FDD to date consists of 256 people with diverse backgrounds ranging from law, academics, activists, to activists Non-Governmental Organizations (NGOs).

This study focuses on one community that encourages the revision of the UU ITE, namely FDD. WAG FDD is quite active, the diverse background of FDD members also makes this forum colorful from the side of the conversation that happens every day. It is interesting to examine what kind of formulation they proposed for the government to immediately revise the UU ITE.

Netnography as a research strategy was once used by Kozinetz in 2002. Backed by the Sturbucks phenomenon, the study aims to explore and analyze some of the meanings and 
symbols on posters surrounding contemporary coffee consumption [2].

While research using netnography study in Indonesia ever done by Irwansyah from University of Indonesia entitled "Labeling Netnography in forum 'Choose Capres' Kaskus". The study looked at the importance of the ideal leader of the members of the online forum community forum kaskuser. Using the combination of qualitative and netnographic content analysis methods to record ideal leadership issues in the discourse of online community forums, it was found that the values of eastern leadership such as fatherhood, selflessness, mastery, simple, populist, patient and sincere are characters ideal leader for Indonesia. By incorporating concepts and findings related to transformational-transactional leadership styles and cultural communication styles high context-low context this research produces four quadrants of the leadership style of kaskuser [3]

The study entitled "Indonesia-Malaysia Border Conflicts in the Online Community Forum and Perspectives of Communities in Border Areas" by Irwansyah, suggests that the border conflict between Indonesia and Malaysia is always associated with differences in perception, understanding, and response. By using the concept of communication conflict from Krauss and Morella, this study analyzes new media and social media based on online discussion forums to find border issues that are often discourse. Using netnography, the textual discourse that causes differences in perception, understanding, and construction is analyzed and compared with the findings of the actual state of the border area with ethnographic methods. The combination of netnographic and ethnographic methods of collecting data, processing data, analyzing data, and discussing potentially border area data between Indonesia and Malaysia is expected to find and describe the actual Indonesia-Malaysia conflict. This study shows that members of online discussion forums do not understand the border context, while local communities show interaction and communication harmonization. Conflict in online community forums is the extension of the actual Indonesia-Malaysia bilateral conflict [4].

Kurniasari, Arisanty, Irmayanti also conducted a study using a netnography study entitled Youtube, the Next TV Generation: Netnography Studies of Commentary Box Features in Youtube (Video D'Academy 2 "Final 3 Big Concert", X-Factors, AXIS ad. 36, Mata Najwa Episode "Rente Hunter Officer: Setya Novanto Vs. Sudirman Said"). This research uses media ecology theory that collaborate with netnography method. This research suggests that in YouTube the three categories of media convergence are technological, economic and cultural. In the future, there will be an official consolidation between television and YouTube, a process whereby the media industry merges with each other to form a larger media industry. Then, the development of television media in the future will also lead to the television model 2.0 by adopting the existing features in Youtube media. Because Youtube is a role model that combines mass media is one way with interactive media through the box commentary feature. This study proves that nowadays people are beginning to switch to new media compared to conventional media. Evidently many people are switching from Television to
Youtube. The features that allow for interactivity in Youtube will most likely be adopted by future television media. Those features are commentary box, viewers feature and icon "like" on Youtube. By using CMC theory, it is proved that judged from the internal and external context of Youtube, there is existence of active participant which in this research named new audience concept. The audience in Youtube media has the characteristics of prosumen (consumer producers), visitors (visitors), resident (fixed or subscribed) and lurkers / stalkers (scouts). All of these types of audiences will color the TV of the future. Youtube audiences who become TV viewers of this future will more often use the language commonly used in everyday life. The language used by Youtube audiences is also expressive as it allows its viewers to use nonstandard, casual and appropriate language to their liking. Then, judging by the concept of user friendliness, Youtube audiences do not know each other, but the interactions that occur between them related to impressions make them feel as if they are bound. So, the interaction in the commentary box keeps the audience connected and integrated with each other because of the similarity of interest or likeness to an impression. Finally, what makes Youtube a future TV is the benefits that can be gained from Youtube's own features, namely replaying activity (can play back the video that aired), features "Skip Ad", freedom in choosing the impressions you want to watch, and the main thing is the audience can watch the show anywhere and anytime without limited space and time. Given the features that enable interactivity and advantages gained from digital-based mass media such as Youtube, future TV projections will lead to a one-way collaboration between mass media and interactive media such as Youtube. This research contributes to a concept called Television 2.0 which will color the world of television future [5].

In contrast to the previously conducted netnographic studies, this study would like to see the cultural entree or value contained in the hypertext narratives of FDD community members in their WAGs. With the perspective of communications policy, this research will formulate policies that favor internet users in Indonesia.

Schau and Gilly explain that netnography reveals and analyzes self-presentation strategies that people use to build a digital self, and netnography has also been used for global ethical studies and peer-to-peer illegal perceptions file-sharing (Cohn and Vaccaro), to investigate consumer activism (Kozinets and Handelman, 1998), and to demonstrate how the creation of knowledge and learning takes place through a reflective 'virtual re-experiencing' discourse among members of an innovative online community [2].

Netnography is ethnography on the internet. A new qualitative research methodology that adapts ethnographic research techniques to assess the culture and emerging communities through computer mediated communications (CMC) communication [2]. Netnography uses public information available in online forums to identify and understand the needs and decisions that affect relevant online groups.

Netnography was originally used as a marketing research technique using public information available in online forums 
to identify and understand needs and influence relevant online consumer group decisions.

Netnography is a method of ethnographic research done to look at social phenomena and user culture in cyber space. Bell (2002) suggests that netnography is a major and important method for seeing the cyber-culture phenomenon on the internet [6].

Virtual community is a social aggregation emerging from the network when people bring long public discussion, with enough feeling, to form a web of personal relationships in the cyber world [2].

As Rheingold puts it, people in online communities joke and debate, participate in intellectual discourse, trade, exchange knowledge, share emotional support, make plans, brainstorm, gossip, fight, fall in love, find friends and losing them, playing games, teasing, creating art, and lots of nonsense [2].

FDD is an online community, an open forum for those who champion digital democracy for all Indonesians without exception. FDD begins with the impetus of revising UU ITE which basically has to fulfill the political rights (opinion and participation) on the internet, rather than overthrow it. This forum invites anyone interested in discussing digital democracy in Indonesia.

Initially, this community utilize wordpress site as a means of sharing with demokrasidigital.wordpress.com address then in December 2014 switch to demokrasidigital.net address. Currently FDD also has WAG created on October 2, 2013. The group now has 256 members.

\section{RESEARCH METHOD}

This research was approached qualitatively using constructivism paradigm. This research uses netnography research strategy. The stages of this netnography research are almost similar to the traditional ethnographic stage. The initial phase begins by making research boundaries and making inquiries, selecting online communities, participating in observations, followed by analyzing data and presenting ethnographic reports. In terms of substance, traditional ethnography and netnography are not much different. In Netnography, netnography is defined as "an ethnographic form adapted for the computer-mediated social world" [2]. In short, netnography is a method for studying cybernetics space (cyberspace). Recently, netnography has been promoted as the only method specifically designed to study the culture and the online community. Kozinets further explains the benefits of netnography in studying online social interactions: “...online interactions are valued as a cultural reflection that yields deep human understanding. Like in-person ethnography, netnography is naturalistic, immersive, descriptive, multimethod, adaptable, and focused on context. Used to inform consumer insight, netnography is less intrusive than ethnography or focus groups, and more naturalistic than surveys, quantitative models, and focus groups. Netnography fits well in the frontend stages of innovation, and in the discovery phases of marketing and brand management."
These netnography advantages make observation methods (often considered "stalking"/lurking) methods, content analysis and text mining used to research online netizens' activities more deeply. Because in principle the same, ethnography and netnography have many similarities. The most fundamental equation of these two methods is to equally emphasize the importance of the researcher's involvement and the importance of context in the depiction of online culture. The difference between these two methods lies in how research is conducted and how anthropologists conduct research. How to search, record and record, store, analyze and display online cultural representations? Looking for data in cyberspace is certainly not the same as field research on a community on the coast of Java, for example. If in ethnographic research, data is obtained primarily through in-depth interviews, in netnographic data primarily derived from hypertext interactions of netizens.

The data collected in this research is primary data and secondary data. Primary data were obtained from online observation and content analysis of the hypertext interactions of members of the WAG FDD community. Secondary data are general data supporting research, derived from previous studies and netbooks, plus books related to social media. From the combination of secondary data and primary data will be obtained a comprehensive analysis.

In this research, the object of research and online observation is done on WAG FDD on the UU ITE in Indonesia. Online observation will be done by observing directly and deeply the hypertext interactions between members of the forum, such as anyone who comments and engages in an active conversation within the WAG. Thus expected the researcher gets the picture and deep study.

The explanation of why the FDD is appropriate to be an observation tool considering the purpose of the research is to provide input to policy makers to accommodate the aspirations of the people who devote their attention and efforts to justice opinion and participate on the internet by creating good and established policies for all internet users in Indonesia.

Online observation is one of the major data collection techniques in netnography. In this study, online observation became the main data collection method because with online observation the researcher can witness directly the social interaction of the subject in virtual world in WAG FDD. WAG makes it possible for members to talk directly or real-time. Researchers will utilize this feature to interact with the subject of his research.

In this research, procedures of netnography methods such as (1) making cultural entree, (2) gathering and analyzing the data, (3) ensuring trustworthy interpretation, (4) conducting ethical research, and (5) providing opportunities for culture member feedback are done.

The first procedure is making cultural entree with have specific questions, identify particular online forums, learn as much as possible about the forums, the groups, and the individual participants. Online communities should be preferred that have either: (1) a more focused and research question relevant segments, topics or groups, (2) higher "traffic" of postings, (3) larger number of discrete messages 
posters, more detailed or descriptively rich data, (5) more between-member interactions.

The second procedure is gathering and analyzing the data. The researcher could be (1) copy form the forums of online community members directly, (2) inscribe the community observations, including its members, interactions, and meanings, (3) classify the messages as primarily on-topic or primarily off-topic, (4) categorize the users as "tourists", "minglers", "devotees", or "insiders", (5) track how "tourists" or "minglers" are socialized and "upgraded" into higher level, (6) record the observations regarding subtexts, pretexts, contingencies, conditions and personal emotions, (7) contextualize the online data.

The third procedure is ensuring trustworthy interpretation to (1) determine the important of research questions and to the authority that will be granted to findings, (2) differentiate between 'netnography' and traditional ethnography, (3) use other methods such as interviews, focus groups, survey or traditional in-person ethnographic if the researcher seeks to generalize to groups other than the populations studied, (4) reflect the limitations of the online medium and the technique.

The fourth procedure is conducting ethical research, are online forums to be considered a private or a public site? What constitutes "informed consent" in cyberspace? Researcher should (1) disclose their presence, affiliations and intentions, to online community members, (2) ensure confidentiality and anonymity to informants, (3) seek and incorporate feedback from online forums members, (4) take a cautious positions on the private vs public issues.

The last procedure is providing opportunities for culture member feedback. Member checks are a procedure whereby some or all of a final research report's findings are presented to the people who have been studied in order to solicit their comments.

\section{RESULTS AND DISCUSSION}

One potential forum were chosen, which had the high amount of traffic, were read by hundreds users, contained many "minglers" and had a large number of "tourist" who come and go with specific queries. The investigation was limited to 206 pages postings (between January and February 2016) that were downloaded and printed. The postings were classified into topic either relevant or not relevant with research question. Permission was sought and granted from the users to users to use direct quotes.

These below are the representative discussion from 206 pages conversation of WAG FDD that analyzed about UU ITE:

TABLE II. USERS CONVERSATION

\begin{tabular}{|l|l|l|l|}
\hline Account & Date & \multicolumn{1}{|c|}{ Comment } & \multicolumn{1}{|c|}{$\begin{array}{c}\text { User } \\
\text { Category }\end{array}$} \\
\hline & $\begin{array}{l}\text { 26 Jan } \\
10: 25\end{array}$ & $\begin{array}{l}\text { Siapa yg bersedia mengcover } \\
\text { persidangan ke-8 kasus Fadli di } \\
\text { Gowa ?! Minta tolong diangkat } \\
\text { karena hari ini pak Bupati datang } \\
\text { ke persidangan. Kawan2 AJI, } \\
\text { media, blogger bisa bantu? }\end{array}$ & \\
& & \\
\hline
\end{tabular}

\begin{tabular}{|c|c|c|c|}
\hline Account & Date & Comment & $\begin{array}{c}\text { User } \\
\text { Category }\end{array}$ \\
\hline & $\begin{array}{l}26 \text { Jan } \\
10: 50\end{array}$ & $\begin{array}{l}\text { Kasus Fadli: } \\
\text { http://makassar.tribunnews.com/20 } \\
\text { 14/12/18/kritik-bupati-gowa-di- } \\
\text { line-pns-ini-dipenjara }\end{array}$ & insider \\
\hline & $\begin{array}{l}26 \text { Jan } \\
11: 00\end{array}$ & $\begin{array}{l}\text { Sudah saya teruskan ke teman2 } \\
\text { media mas Dam }\end{array}$ & devote \\
\hline & $\begin{array}{l}26 \text { Jan } \\
11: 01\end{array}$ & 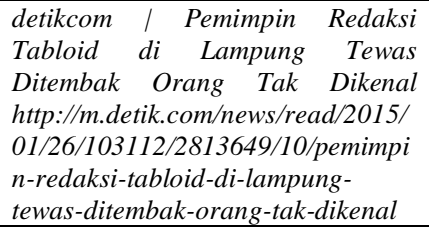 & mingler \\
\hline & $\begin{array}{l}26 \text { Jan } \\
11: 02\end{array}$ & $\begin{array}{l}\text { OOT: Monggo yang ingin mencoba } \\
\text { WhatsApp lewat Web, langkah ini } \\
\text { bisa dipraktikkan. Biar lebih lancar } \\
\text { dan lincah diskusinya.. :) } \\
\text { https://storify.com/temukonco/wafor } \\
\text { web }\end{array}$ & mingler \\
\hline & $\begin{array}{l}26 \text { Jan } \\
12: 02\end{array}$ & $\begin{array}{l}\text { Breaking news! TEDJO } \\
\text { DILAPORKAN KASUS } \\
\text { PELECEHAN SEXUAL! Kisahnya, } \\
\text { suatu hari Tedjo pulang kampung } \\
\text { dan bertemu Surti di sawah. Tesjo } \\
\text { memaksa Surti berbuat tidak } \\
\text { senonoh. Surtipun lari sambil } \\
\text { menangis. Lalu Tedjo berteriak, } \\
\text { "Surti Fuck You!". Demikian } \\
\text { menurut penuturan Jamrut dalam } \\
\text { lagunya. }\end{array}$ & mingler \\
\hline & $\begin{array}{l}26 \text { Jan } \\
12: 04\end{array}$ & Hahahah & mingler \\
\hline & $\begin{array}{l}26 \text { Jan } \\
12: 05\end{array}$ & Aseeem. & mingler \\
\hline & $\begin{array}{l}26 \text { Jan } \\
12: 21\end{array}$ & $\begin{array}{l}\text { Update: kasus Fadli tidak juga } \\
\text { dihadiri oleh bupatinya hari ini ke } 8 \\
\text { kalinya. Mari kita serukan bersama } \\
\text { kasus ini tidak layak diteruskan. }\end{array}$ & insider \\
\hline & $\begin{array}{l}26 \text { Jan } \\
12: 21\end{array}$ & Setuju kita ramein djkt & mingler \\
\hline & $\begin{array}{l}26 \text { Jan } \\
12: 21\end{array}$ & Krn dsana riskan & mingler \\
\hline & $\begin{array}{l}26 \text { Jan } \\
12: 32\end{array}$ & Yuk! Lawan! & mingler \\
\hline & $\begin{array}{l}26 \text { Jan } \\
12: 40\end{array}$ & Setuјииии! & mingler \\
\hline & $\begin{array}{l}26 \text { Jan } \\
13: 02\end{array}$ & Knonologis kasus dong & mingler \\
\hline & $\begin{array}{l}26 \text { Jan } \\
13: 12\end{array}$ & $\begin{array}{l}\text { Tulis di safenet Mang } \\
\text { Kita tinggal share linknya. }\end{array}$ & mingler \\
\hline & $\begin{array}{l}26 \text { Jan } \\
13: 31\end{array}$ & $\begin{array}{l}\text { Kasus Fadli: } \\
\text { http://makassar.tribunnews.com/20 } \\
\text { 14/12/18/kritik-bupati-gowa-di- } \\
\text { line-pns-ini-dipenjara }\end{array}$ & insider \\
\hline & $\begin{array}{l}26 \text { Jan } \\
13: 32\end{array}$ & $\begin{array}{l}\text { Tulisan lain: } \\
\text { http://rplr.co/1E3Scmg }\end{array}$ & insider \\
\hline & $\begin{array}{l}26 \text { Jan } \\
13: 35 \\
\end{array}$ & $\begin{array}{l}\text { manteman, } I^{\text {anggaran }} \text { antuk } \\
\text { acara dialog } 2 \text { feb spt itu }\end{array}$ & devote \\
\hline & $\begin{array}{l}26 \text { Jan } \\
13: 35\end{array}$ & adakah yg mau saweran? & devote \\
\hline & $\begin{array}{l}26 \text { Jan } \\
13: 35\end{array}$ & salah, 3 frb 2015 & devote \\
\hline & $\begin{array}{l}26 \text { Jan } \\
13: 36\end{array}$ & $\begin{array}{l}\text { Biar jelas sedikit, itu adalah } \\
\text { cuplikan dari proposal acara kita. } \\
\text { Dibutuhkan dana 56jt dan baru } \\
\text { terkumpuk 28jt. Apakah masih ada }\end{array}$ & devote \\
\hline
\end{tabular}




\begin{tabular}{|c|c|c|c|}
\hline Account & Date & Comment & $\begin{array}{c}\text { User } \\
\text { Category }\end{array}$ \\
\hline & & yg mau saweran? & \\
\hline & $\begin{array}{l}26 \text { Jan } \\
13: 36\end{array}$ & Masih koq lbh pers, ntr menyusul ya & devote \\
\hline & $\begin{array}{l}26 \text { Jan } \\
13: 37\end{array}$ & $\begin{array}{l}\text { Mau dicantumkan di proposal skrg } \\
\text { atau nanti2 saja? ToR akan } \\
\text { dikirimkan berikut finalisasi } \\
\text { proposal jam } 2 \text { ini }\end{array}$ & insider \\
\hline & $\begin{array}{l}26 \text { Jan } \\
13: 37\end{array}$ & Nanti saja & devote \\
\hline & $\begin{array}{l}26 \text { Jan } \\
13: 37\end{array}$ & oke & devote \\
\hline & $\begin{array}{l}26 \text { Jan } \\
13: 38\end{array}$ & Pas sawerannya dterima & devote \\
\hline & $\begin{array}{l}26 \text { Jan } \\
13: 47\end{array}$ & iLab menyusul utk saweranya & mingler \\
\hline & $\begin{array}{l}26 \text { Jan } \\
13: 49\end{array}$ & Ini dkasih kesiapa ya sawerannya? & devote \\
\hline & $\begin{array}{l}26 \text { Jan } \\
13: 49\end{array}$ & $\begin{array}{l}\text { Sorry, sawerannya buat acara apa } \\
y a \text { ? }\end{array}$ & devote \\
\hline & $\begin{array}{l}26 \text { Jan } \\
14: 02\end{array}$ & Acara: s.id/fddmeeting & insider \\
\hline & $\begin{array}{l}26 \text { Jan } \\
14: 02\end{array}$ & Acara: http://s.id/fddmeeting & insider \\
\hline & $\begin{array}{l}26 \text { Jan } \\
14: 03\end{array}$ & $\begin{array}{l}\text { Finalisasi ToR dan proposal sedang } \\
\text { dikirim ke kawan2 }\end{array}$ & insider \\
\hline & $\begin{array}{l}26 \text { Jan } \\
14: 03\end{array}$ & Sabarya & insider \\
\hline & $\begin{array}{l}26 \text { Jan } \\
14: 08\end{array}$ & APJII 5jt ya... & devote \\
\hline & $\begin{array}{l}26 \text { Jan } \\
14: 08\end{array}$ & terima kasih pak Semmy & tourist \\
\hline & $\begin{array}{l}26 \text { Jan } \\
14: 12\end{array}$ & Makasih ya & mingler \\
\hline & $\begin{array}{l}26 \text { Jan } \\
14: 15\end{array}$ & $\begin{array}{l}\text { Utk kasus fadli dgoa mks } \\
\text { rencananya tim kuasa hukum yg } \\
\text { djkt akan konpres hari rabu besok, } \\
\text { lokasi akan diupdate secepatnya }\end{array}$ & devote \\
\hline & $\begin{array}{l}26 \text { Jan } \\
14: 09\end{array}$ & $\begin{array}{l}\text { Aku usahain lebih. Proposal kirim } \\
\text { ke spangerapan@apjii.or.id }\end{array}$ & devote \\
\hline & $\begin{array}{l}26 \text { Jan } \\
14: 25\end{array}$ & Siap pDukung! & insider \\
\hline & $\begin{array}{l}26 \text { Jan } \\
14: 26\end{array}$ & $\begin{array}{l}\text { PVI blm bisa ya. Begitu ada kita } \\
\text { langsung bantu deh. }\end{array}$ & tourist \\
\hline
\end{tabular}

\begin{tabular}{|l|l|l|l|}
\hline Account & Date & \multicolumn{1}{|c|}{ Comment } & $\begin{array}{c}\text { User } \\
\text { Category }\end{array}$ \\
\hline & & & \\
\hline & $\begin{array}{l}26 \text { Jan } \\
14: 29\end{array}$ & Siap dukung! & tourist \\
\hline & $\begin{array}{l}26 \text { Jan } \\
14: 46\end{array}$ & Logo FDD buatan mas MT & insider \\
\hline
\end{tabular}

\section{CONCLUSION}

This study shows that generally member of FDD agreed to revise the UU ITE. This research is limited to UU ITE issue by FDD in Whats App Group. Next research using netnography method can be done to find the cultural entree or value of another problem statement with other online community.

\section{ACKNOWLEDGMENT}

The authors would like to express heartfelt thanks to P3KM Institut Teknologi dan Bisnis Kalbis (Kalbis Institute) for providing financial support.

\section{REFERENCES}

[1] APJII and Puskakom UI, Profil Pengguna Internet Indonesia 2014 Jakarta: APJII, 2015, in press.

[2] R.V. Kozinets, Netnography: Doing Etnographic Research Online. London: SAGE, 2010, in press.

[3] Irwansyah, Labelling Netnografi dalam forum 'Pilih Capres' Kaskus. Universitas Indonesia, 2014

[4] Irwansyah, "Indonesia-Malaysia border conflicts in the online community forum and perspectives of communities in border areas," Jurnal Communicate Universitas Jayabaya vol. 1 no. 2, 2016.

[5] N. Kurniasari, M. Arisanty and M. Irmayanti, "Youtube, The Next TV Generation: Netnography Studies of Commentary Box Features in Youtube (Video D'Academy 2 "Konser Final 3 Besar", X-Factors, AXIS ad Iritology No. 36, Mata Najwa Episode Pejabat Pemburu Rente "Setya Novanto Versus Sudirman Said")," Conference Proceeding The 3rd Indonesia International Conference on Communication (INDO ICC) "Communication \& Collaboration" FISIP UI, Depok Campus ThursdayFriday 10-11 December 2015. Departement of Communication, Faculty of Social and Political Sciences, University of Indonesia, 2015, in press.

[6] R. Nasrullah, Media Siber (Cybermedia): Teori dan Riset. Jakarta: Kencana, 2014, in press. 